\title{
Conservation of a Wooden Tomb-Marker from the Jewish Cemetery of Algarrobos in Argentina
}

\author{
Paula V. Alfieri *, Rosana Lofeudo, Guadalupe Canosa, Fabian Iloro and Luis P. Traversa \\ Laboratorio de Entrenamiento Multidisciplinario para la Investigación Tecnológica (LEMIT), \\ Calle 52 e/121 y 122, La Plata 1900, Argentina; rosanalofeudo@yahoo.com.ar (R.L.); \\ guadalupecanosa@yahoo.com.ar (G.C.); patrimonio@lemit.gov.ar (F.I.); direccion@lemit.gov.ar (L.P.T.) \\ * Correspondence: paulaalfieri@gmail.com
}

Received: 2 March 2018; Accepted: 20 May 2018; Published: 22 May 2018

\begin{abstract}
The state of conservation of some tombs in the Jewish Cemetery of Algarrobos in Colonia Mauricio, Buenos Aires, Argentina was evaluated. A lot of material was found, but only two tomb-markers were done on wood. They were in a state of serious deterioration, so these were defined as an object of study. The tomb-markers, which had been established by the Jewish immigrants from Russia at the end 19th century, were made of South American tree known as Aspidosperma Quebracho Blanco and suffered both biological (from fungal decay and insect attack) and mechanical deterioration (cracks and fissures due to weathering, and discoloration due to ultraviolet radiation). Thus, the aim of this paper was the conservation of one of the two remaining wooden tomb-markers found, using impregnant based on non-toxic siloxanes employing sol-gel technology in order to increase the readability of epitaphs and reliefs found at the tomb-marker. The treatment with this modern technology resulted in the excellent performance of wooden tomb-maker conservation. The structural consolidation and cracks sealing were achieved. It avoided the detachment of material and the appearance of natural veins; furthermore, it improved the reading of the epitaphs and reliefs.
\end{abstract}

Keywords: wood; heritage; tomb-marker; siloxane; conservation; protection

\section{Introduction}

The cemetery of Algarrobos is located in the old Colonia Mauricio, Carlos Casares province of Buenos Aires, Argentina $(38.9053823,-63.1437093,234)$ on the margins of the homonymous lagoon. It was founded by the Jewish Colonization Association in 1891, and it is a reflex of an important historic event: the Jews' establishment in Argentina, which is linked to the massive Jewish immigration to our country, mainly from the Russian Empire at the end of the 19th century. At present, the cemetery is active, and it is one of the most emphasized places inside the Buenos Aires tourist circuit [1-5].

During the month of March 2017, we made a technical visit to the Jewish Cemetery of Algarrobos (together with Heritage Director of Tourism and Museums of Carlos Casares Municipality) in order to examine and evaluate the state of conditions (see Figure 1). In the inspection visit, we identified many pathologies of material degradation caused either by weathering or by vandalism, which, in some cases, were linked with the weathering of the materials and, in others, by vandalism (see Figure 2). Tomb-markers of different materials were found, but only two were of wood. They were in a seriously deteriorated condition, so these were defined as the object of study.

The tomb-markers observed during our inspection, as well as those documented during previous surveys [1-3], were made of different materials, although there was a large predominance of marble, followed by granite, wood, and other types of ornamental rocks (see Table 1). It was interesting that the use of wood as a tomb-marker was confined to the first four decades, although always in a notorious minority with respect to marble (Table 1). It was feasible to suppose, however, that this type 
of tomb-marker was under-represented due to its lower preservation. It would be possible that several tombs currently without tomb-markers originally were of this type [4-8].

Table 1. Use of materials in tomb-markers over time [1].

\begin{tabular}{ccccccc}
\hline Decade & Wood & Marble & Granite & Stone & No Data & Total \\
\hline $1891-1900$ & 1 & 13 & - & - & - & 14 \\
$1901-1910$ & 1 & 31 & 1 & 3 & 8 & 44 \\
$1911-1920$ & 3 & 27 & 1 & 1 & 2 & 34 \\
$1921-1930$ & 1 & 5 & 1 & - & - & 7 \\
$1931-1940$ & - & 11 & - & - & 2 & 13 \\
$1941-1950$ & - & 8 & 3 & 1 & 2 & 14 \\
$1951-1960$ & - & 5 & 1 & - & 2 & 8 \\
$1961-1970$ & - & 4 & 6 & - & 3 & 13 \\
$1971-1980$ & - & 1 & 1 & - & 2 & 4 \\
$1981-1990$ & - & - & 5 & - & 5 & 10 \\
$1991-2000$ & - & 1 & 1 & - & 3 & 5 \\
$2001-2010$ & 5 & 1 & 3 & - & 59 & 68 \\
No data & 5 & 1 & 3 & - & 59 & 68 \\
Total & 11 & 107 & 23 & 5 & 89 & 235 \\
\hline
\end{tabular}
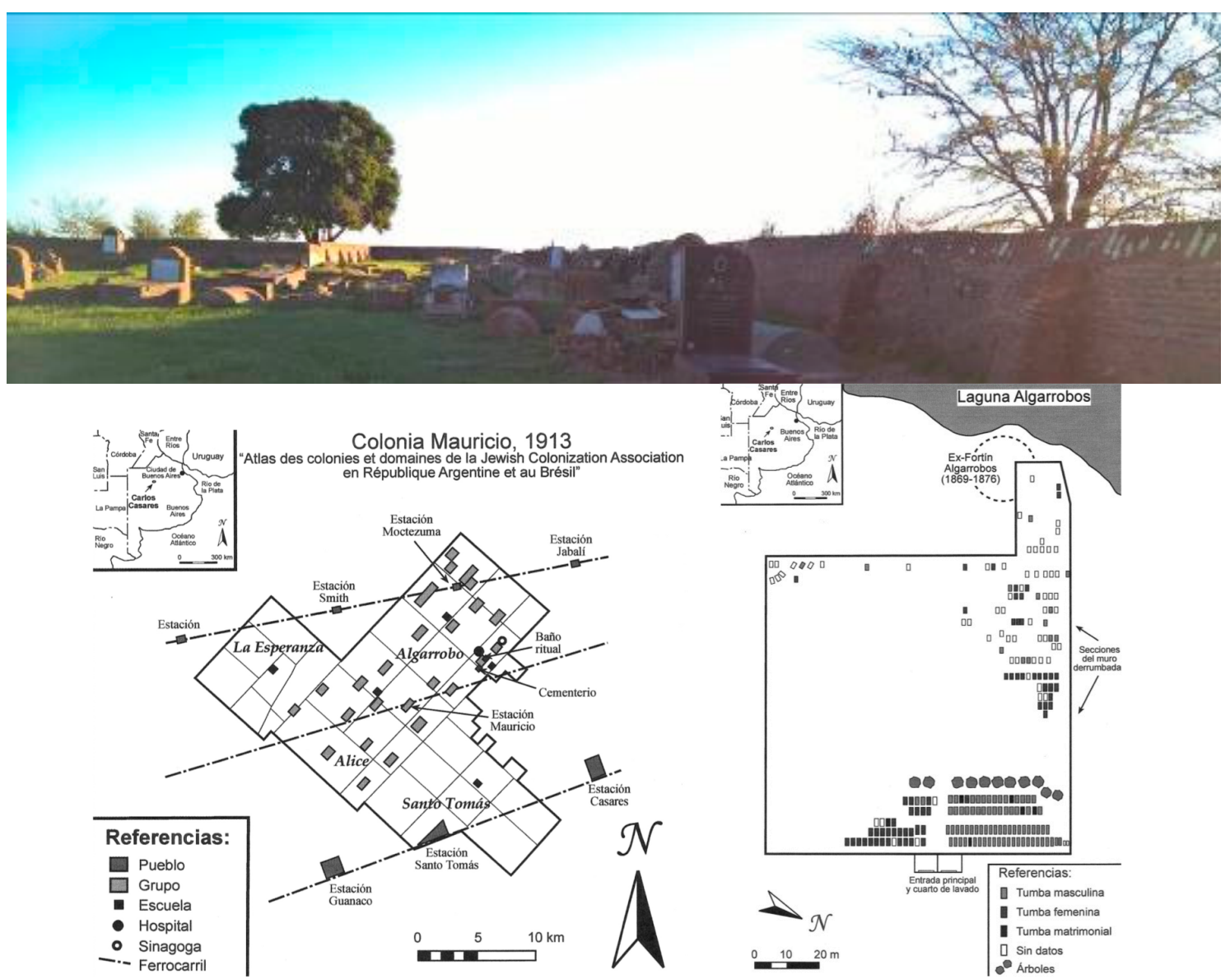

Figure 1. Current photo of the cemetery and map of the Colonia Mauricio (redrawn from Atlas des colonies et domaines of the Jewish Colonization Association in République Argentine et au Brasil, edited by the JCA, 1913 [1]. 


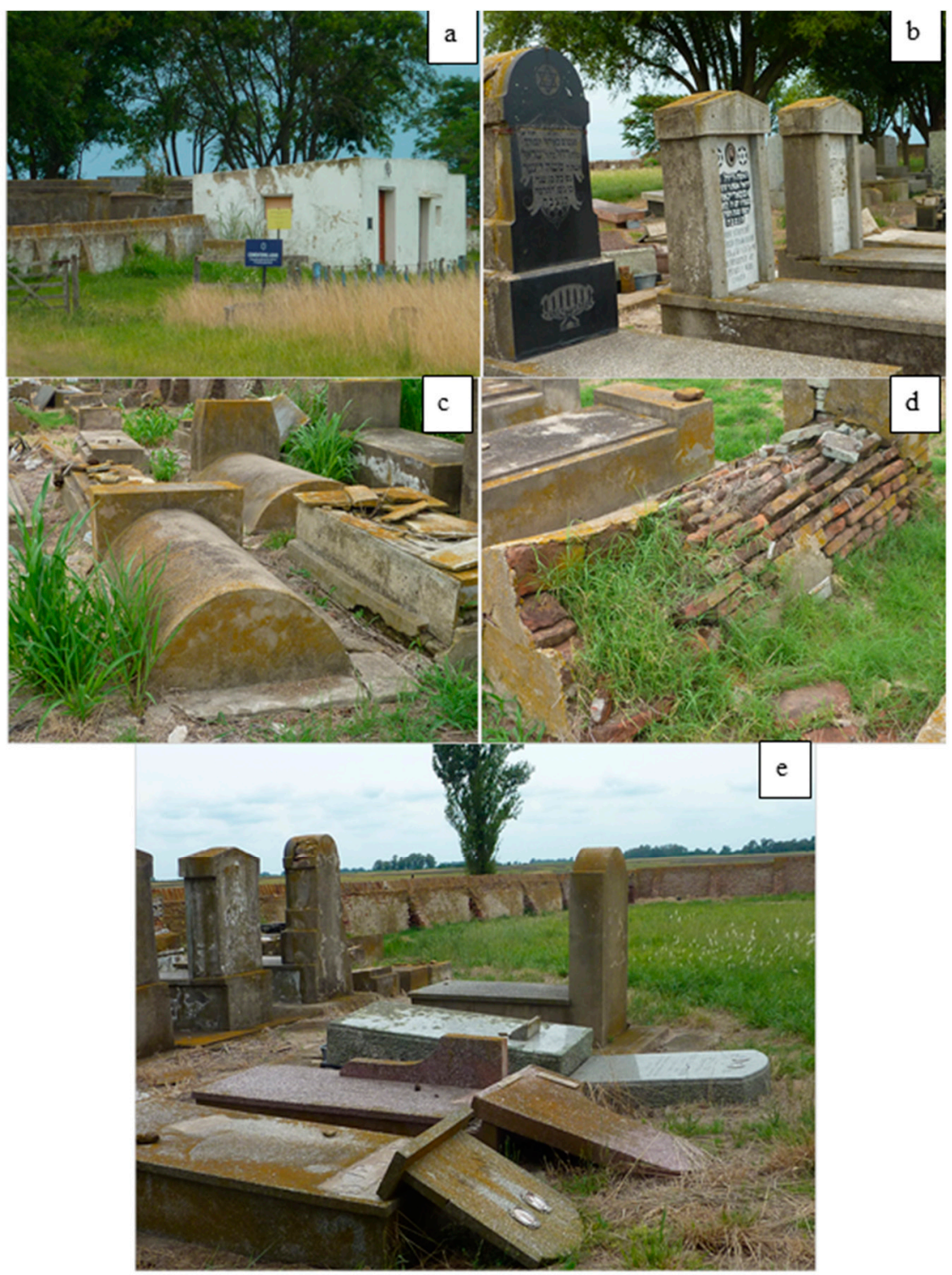

Figure 2. Conditions of the Algarrobo Cemetery: (a) view of the premises located in the front of the cemetery; (b) detail of tombs: stones with marble is observed; (c) view of the sector of the graveyard with tombs built in shape of vault; (d) detail of one of the tombs made with common ceramic bricks; and (e) view of some tombs affected by vandalism and the wall surrounding the cemetery.

As mentioned, all the tomb-markers were damaged. Some of them were or have been relieved, restored, and translated into headstones, providing important information about social structure and ethnic conditions (the symbolic space that reflects the ethnic construction of identities, class, and genre), as well as their changes across time since, it is a social framework that includes features of exclusion (suicides or epidemics), personal links, and kinship. In this case, the use of wood as a tomb-marker could be explained by the lack of economic resources of the Jews who lived, at that time, in the Mauricio Colony, estimating that the constructions of the tombs and tomb-markers were done with the resources available in the field $[9,10]$. Therefore, their conservation is relevant.

In order to undertake conservation, the current consolidate treatments' development based on non-polluting technological products for the protection of heritage is needed. Also, it is necessary to build a bridge between the basic knowledge generated as a product of scientific research and applied science. 
Currently, consolidating substances and repellents based on organosilicon compounds are used in construction (e.g., brick, concrete, plaster, etc.), but they are not widely studied in wood treatments [11-17]. Siloxanes are very small molecules that, when applied to the surface of a suitable substrate, penetrate deeply. They react with the substrate and impart durability. Many protective treatments are applied on wood by impregnation to make it water repellent, thus avoiding the pathologies that this causes (loss of dimensional stability, growth of microorganisms, efflorescence, etc.). Organosilicon compounds such as silanes and siloxanes are widely used as consolidators and water repellents in concrete and other materials in construction [17-20].

The use of the silanes for materials protection is due to the fact that they are capable of forming bonds with the substrate across the inorganic part $\left(\mathrm{OR}^{\prime}\right)$ of the molecule (it is restricted to materials that they have $-\mathrm{OH}$ in their chemical composition) via the sol-gel process: during hydrolysis, the union $\mathrm{Si}-\mathrm{O}-\mathrm{C}$ is formed to give silanoles $(\mathrm{Si}-\mathrm{OH})$, which later reacts with the oxides and / or present hydroxides in the surface of the material, forming Si-O-Substrate bonds [21-25].

Considering the above-mentioned details, the objective of this report is to present the application of the novel, environmentally friendly methodology of conservation based on siloxanes for the impregnation of a wooden tomb-marker, in order to increase the readability of epitaphs and reliefs.

\section{State of Condition of the Wooden Tomb-Marker}

In the first instance, wood was identified using observations of magnifying glass $(10 \times)$ and microscope $(40 \times)$ without staining to observe characteristics in terms of vessels, parenchyma, and rays, which allowed the identification of species through the support of dichotomous keys [26-29]. Finally, it was corroborated by comparing wood cuts of the identified species. The observations carried out indicated that the wood species is Quebracho Blanco (Aspidosperma Quebracho Blanco).

Aspidosperma Quebracho Blanco, Apocinaceae, is considered one of the most important commercial species in the region of Chaco, Argentina, Figure 3.

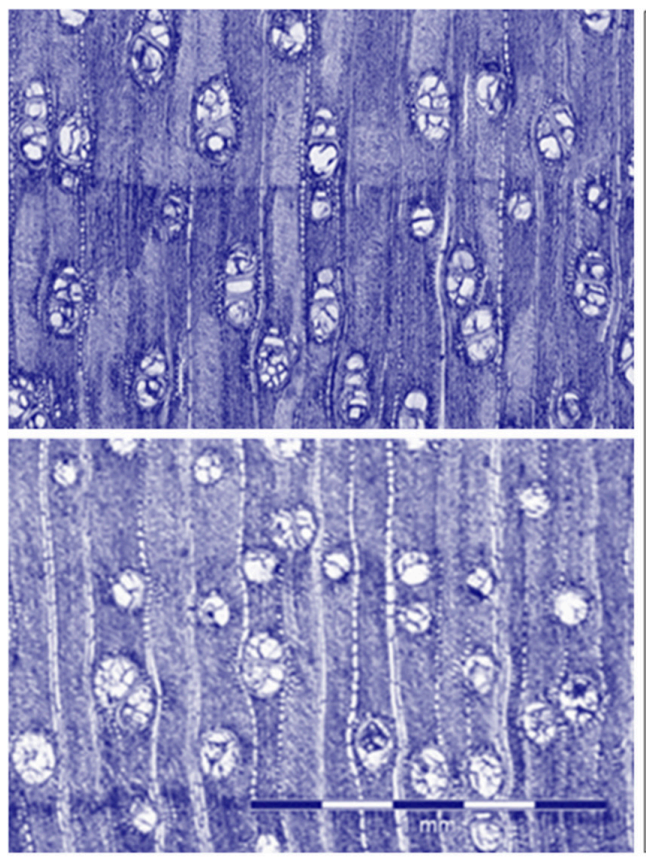

(a)

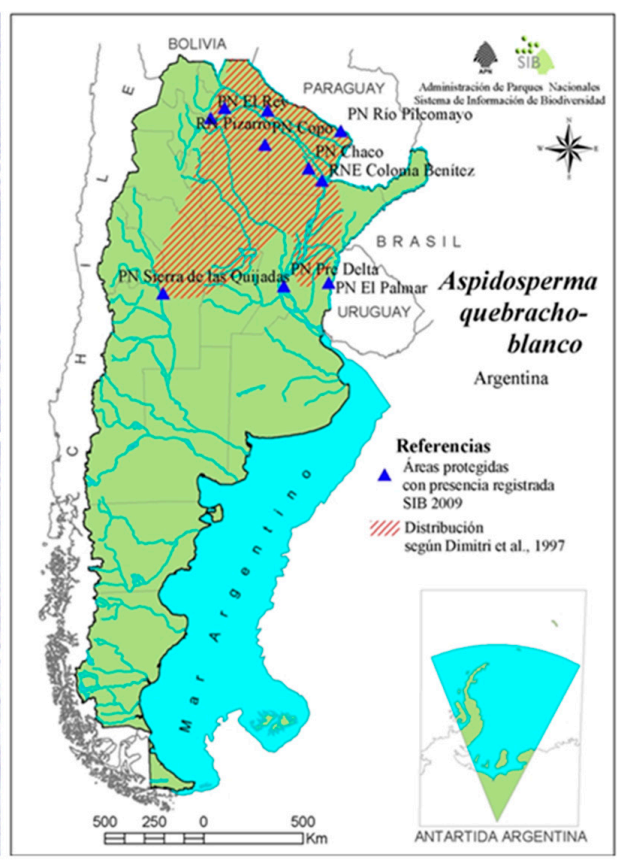

(b)

Figure 3. (a) Identification of wood species observed in ultrathin sections by optical microscope and compared with cuts of xylotheque (down); (b) The geographical distribution at the country level of the identified wood species was analyzed, as well as the feasibility of transporting them from that region for the purpose of understanding why wood was used as tomb-markers. 
In general, quebracho wood has good technological characteristics in relation to hardness and workability, but it presents difficulties in certain applications due to its high hygroscopicity, poor dimensional stability, and difficulties in drying. Therefore, it tends to suffer contractions and warping. With this information, the geographic distribution at the country level of the identified wood species was analysed, as well as the feasibility of transporting them from that region to Carlos Casares. It was carried out in order to reconstruct the history of the time that dates the wood.

The use of a material such as wood could be interpreted as clear evidence of different social conditions: This idea was brought from the Chaco region by rail to be used in the construction of structures. The wood origin was also very typical of the decade, since the northern area has been historically a provider of native species.

The deterioration grade was determined by observation and recording photography at first, and then relevant sampling was analyzed in the laboratory to determine the type of material, types of degradation, and level and cause of degradation. Pathologies Identification was made by visual observation and magnifying glass $(10 \times)$.

The wood tomb-marker studied was in a state of advanced deterioration; the wood had a major crack that divided it into two parts, as well as other fissures and longitudinal and transverse cracks of lesser magnitude.

In addition, in the lower part there was a loss of material, which was the product of brown rot fungi decay, as well as grey surface coloration caused by exposure to UV rays of sunlight; black rot indicated the deterioration caused by imperfect fungi and small cavities belonging to xylophage insects (see Figure 4). The whole set of pathologies found would justify the loss of structural stability observed, as well as the impossibility of a correct reading of the reliefs and epitaphs

Characterization and measurement of the degree of deterioration of the wood asset were studied using images analyzed with ImageJ software, in order to determine the degree of affection of the wood to be treated. The measurement is according to grey's difference: the lighter wood represents greater degradation relative to the whole piece. The result was that the wood had a $60 \%$ material degradation (see Figure 5).

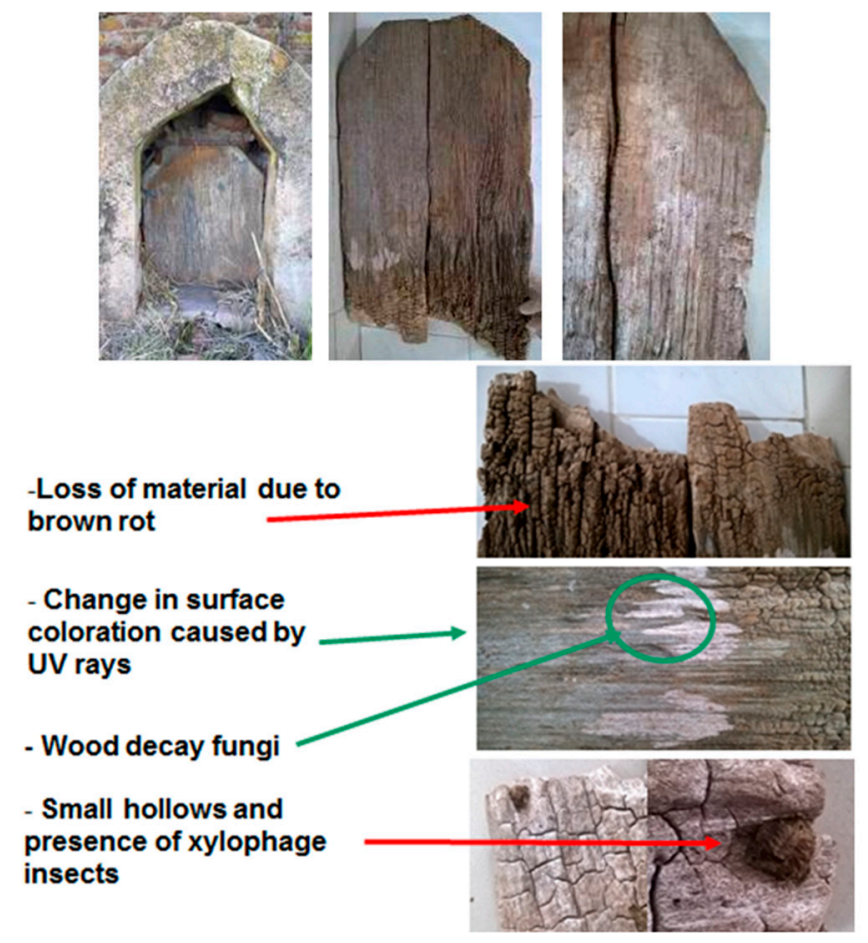

Figure 4. State of deterioration of a wooden tomb-marker, in which there is loss of material and a large biological decay belonging to a decay fungus covering it. 


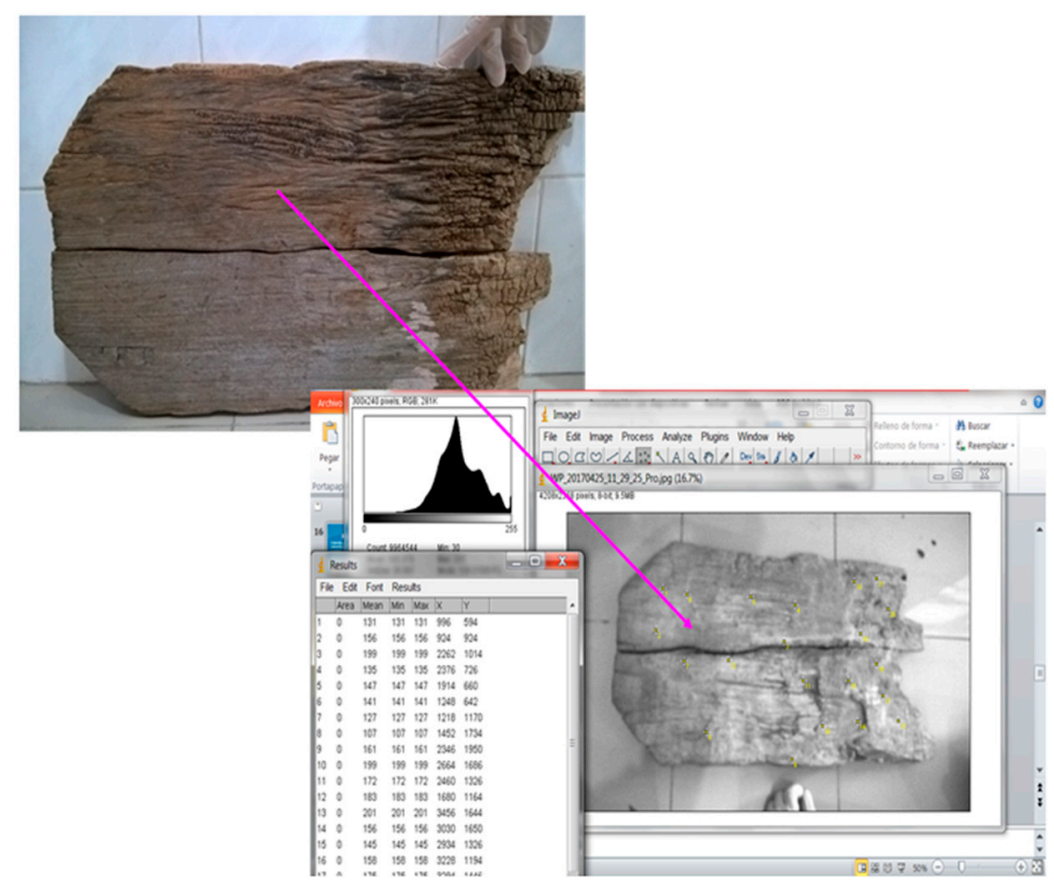

Figure 5. Determination of wood degradation using Image analysis.

\section{Stages of Conservation}

The principles of conservation employed were involved minimal intervention and minimal environmental impact. The formulations for cleaning and protection were developed based on the following criteria.

Cleaner formulation consisted of chlorides water $(3 \%)$ in deionized water. The protective formulation was formulated with siloxanes from commercial precedence (Sika guard S1) in 50\% $v / v$, an organic clarified solvent (double clarified flax oil) as vehicle in $30 \% v / v$, and a curing controller of vegetable origin (turpentine) in $20 \% v / v$.

Cleaning and surface preparation was carried out with the traditional methods of cleaning, and surface preparation was used, generating a soft abrasion and tow. The cleaner formulation was applied with semi dry oakum, rubbing softly to remove surface dirt. The tow was only used for the removal of environmental fungi deposited on the surface (mold, imperfect, etc.). The cleaning procedure was applied on one of the faces, leaving it stationary for 4 days. Then, the same technique was applied on the other side of the tomb-marker, since the latter had graffiti and epitaphs.

Conservation formulation was based on the development of a correct formulation and its application with a brush, treating as if the solutions were like a stain (without film formation):

(i) In the first application, the above-defined protective formulation was diluted with turpentine $50 / 50 \% v / v$ formulation/turpentine.

(ii) The following two successive applications were (1) the formulation diluted $25 / 75 \% v / v$ formulation/turpentine and (2) protective formulation without dilution.

(iii) The face of the tomb-marker without graffiti and epitaphs was first exposed to treatment. The drying time between the applications was $24 \mathrm{~h}$. Once the treatment of the face was completed, it was exposed to the seven day drying phase before the treatment of the other face was started. The treatment of the face with graffiti and epitaphs was done in accordance with the same methodology.

(iv) Finally, the tomb-marker was exposed to controlled conditions of temperature and humidity for three weeks to allow correct curing (sol-gel). 


\section{Results and Discussion}

In order to conserve and consolidate at the beginning of the enhancement of tomb-markers, the appearance of the wood changed radically, with only a removal of superficial environmental impurities. After cleaning, protective system was applied. It was an impregnant treatment that penetrated deeply without forming a film or occluding natural hollows of the wood (see Figure 6A,B).

As a main result, rehydration was observed, generating an improved aesthetic appearance, as well as the sealing the cracks and micro cracks. In addition, the structural consolidation of the part most compromised by the brown rot mentioned was observed. Altogether, this allowed one to observe the detachment of material and the appearance of natural veins. In addition, an improvement in the reading of the epitaphs and reliefs was achieved (see Figure 6C,D).

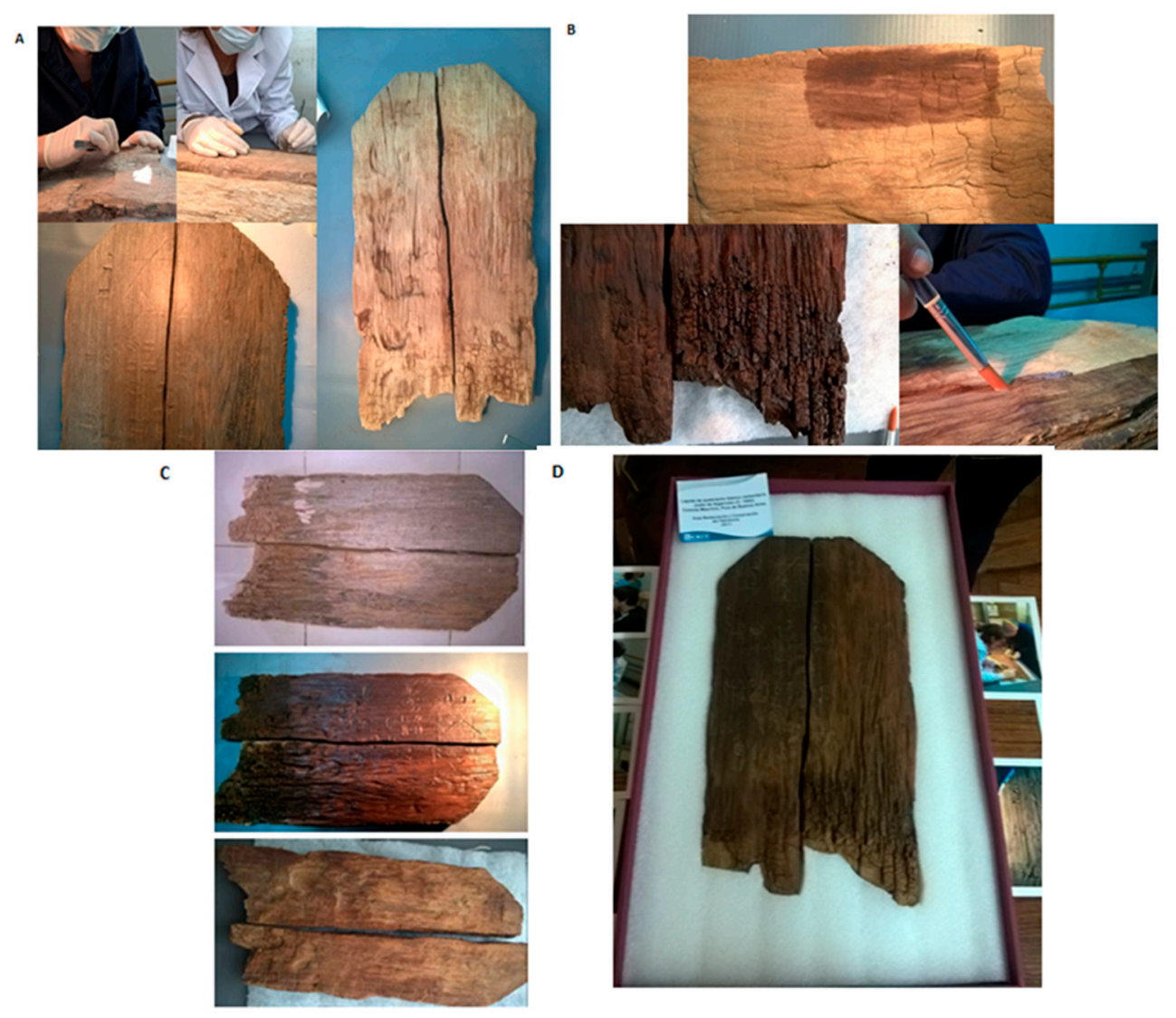

Figure 6. Appearance of a tomb-marker in different stages of conservation: (A) cleaning; (B) treatment application; (C) the difference between the wood condition when it was collected and when it was treated (in order up and down); and (D) the tomb-marker finished and packed to be given to the Municipality.

Regarding the study of protective performance, two non-invasive tests were carried out: (1) The weight variation of the tomb-marker, to extrapolate the absorption and desertion of water taken from the environment, and (2) the contact angle. The contact angle is defined as the angle that a drop forms when it comes in contact with the substrate; the measurement and value of that angle will indicate the degree of wettability and therefore the degree of hydrophobicity that the surface of the substrate presents.

On the other hand, it was observed that the monocomponent and water-repellent siloxanes impregnants were water-based. Therefore, they are a product that is harmless to health and has the peculiarity of being able to penetrate, producing a lasting hydrophobization, while at the same 
time allowing the diffusion of water vapor in both directions, which accompanies the natural watery movement of the wood, giving it dimensional stability [17-19].

In comparison with other wood conservation treatments, this did not generate changes in tomb-markers, because the siloxane is retained inside wood by chemical bonds, so there lixiviation does not occur. On the other hand, this treatment allows natural wood movements and natural water absorption and desorption, which generates excellent dimensional stability and ensures the wood will not crack, as happens with the treatments with resins. The chemical inorganic characteristic of siloxanes also contributes to the wood being less biodegradable and gives it fire-retardant characteristics. Other properties observed of the proposed impregnate are the reduction of water absorption by capillarity, which does not normally change the aesthetic appearance of the substrate, because it does not affect the wood natural colour like, for example, the treatment with PEG. Also, it highlights natural veins $[30,31]$.

The weight-checks were performed daily for 3 weeks, and weight variation was $3 \% \pm 1 \%$, which is not significant, since naturally the wood loses and absorbs moisture. It was concluded that the treatment improved the dimensional stability.

The contact angle measurement was $130^{\circ}$, which translates into a hydrophobic material, verifying greater water repellency of the treatment (see Figure 7).

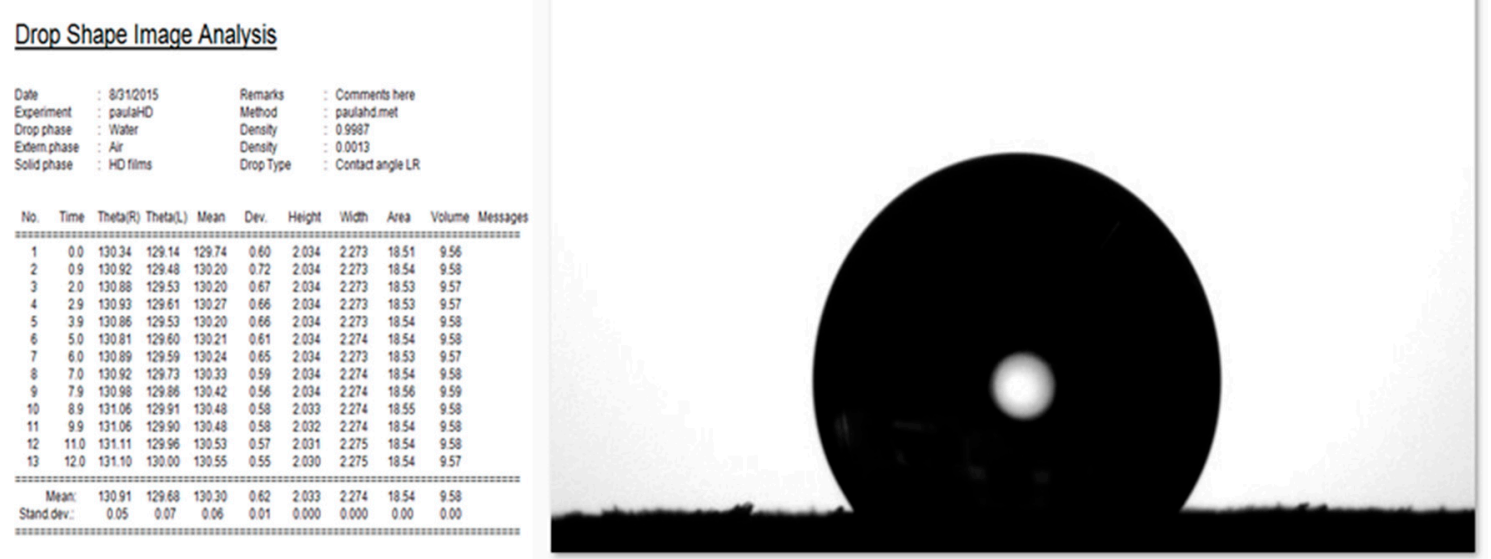

Figure 7. Results of the contact angle test, which demonstrates the hydrophobicity of the treatment.

In previous works in which performance was studied as a protective and consolidating system of a stain-based formulation of siloxanes in woods of different species by surface treatment in order to protect wood from heritage buildings [16-22], it was shown that the application of this formulation reverses the deterioration of a piece of wood by $30 \%$, acting as a biocide, rehydration, and crack sealant.

Regarding reversibility, preliminary results showed that treatment can be removed with alcohol without any effect in wood (under study).

\section{Conclusions}

The structural consolidation and crack sealing were achieved. They avoided the detachment of material and the appearance of natural veins, as well as an improvement in the reading of the epitaphs and reliefs.

This method can be considered innovative, not only for the ease of application, but also because with this technique the biological agents are exterminated; it is hydro-repellent and acts as a biocide.

The conservation technique used in this heritage asset can be applied in similar cases (it has already been implemented in other heritage and non-heritage assets, with excellent results in terms of improving dimensional stability). 
This treatment was relevant, since it exceeds the traditional methods of conservation, because it does not use toxic solvents (environmentally friendly), it does not form an internal polymer structure, and it has shorter curing time, among others.

The identification of the wood species used in the tomb-marker and its place of origin allowed one to reconstruct a part of history: the use of wood can be explained by the lack of economic resources of the Jews who lived, at that time, in the Mauricio Colony, estimating that the constructions of the tombs and tomb-marker were done with the resources available in the field. This idea was brought from the Chaco region by rail to be used in the construction of structures.

Funding: This research was funded by [Comisión de Investigaciones Científicas] grant number [428/16] Project "State of conservation of the architectural heritage: Techniques of repair and promotion of possible tourist circuits in localities, towns and cities of the province of Buenos Aires "subsidized by the CICPBA within the program" within the program" Innovation and Transfer Projects in Priority Areas of the Province of Buenos Aires".

Acknowledgments: To Teresa Acedo, Director of Heritage, Tourism, and Museums of the Municipality of Carlos Casares; Ezequiel Sota; Sebastian Marquez; and to INIFTA for the collaboration on this work.

Conflicts of Interest: The authors declare no conflicts of interest.

\section{References}

1. Leoni, J.B.; Acedo, T.; Tamburini, D.; Scarafia, G. Cambio y continuidad en la materialidad funeraria del cementerio judío Algarrobos, Colonia Mauricio (Carlos Casares, Provincia de Buenos Aires). Revista de Arqueología Histórica Argentina y Latinoamericana 2011, 5, 35-65.

2. Acedo, T.; Schteimberg, D. Cementerio judio de Algarrobos, Sitio Histórico Provincial. Relevamiento e Identificación de Datos; MS. Carlos Casares: Buenos Aires, Argentina, 2005.

3. Acedo, T. Encuentro con nuestro Patrimonio-La experiencia realizada en la localidad Bonaerense de Carlos Casares. In Actas del XIII Congreso Nacional de Arqueología Argentina, Tomo 2; Facultad de Filosofía y Humanidades, Universidad Nacional de Córdoba: Córdoba, Argentina, 1999; pp. 235-245.

4. Anderson, T.G. Czech-Catholic cemeteries in East-Central Texas: Material culture and ethnicity in seven rural communities. Mater. Cult. 1993, 25, 1-18.

5. Aranovich, D. Breve Historia de la Colonia Mauricio (Memory, PhD); Serie Los Pueblos $\mathrm{N}^{\circ}$; Editora del Archivo, Ed.; Carlos Casares: Buenos Aires, Argentina, 2002.

6. Sigwald Carioli, S. Colonia Mauricio, Génesis y Desarrollo de un Ideal, 2nd ed.; Editora del Archivo, Ed.; Centro Cultural José Ingenieros, Archivo Histórico Antonio Maya: Carlos Casares, Argentina, 1991.

7. Sigwald Carioli, S. Colonia Mauricio: Revalorización de su Trascendencia; Colonia Mauricio, 100 Años, Publicación Oficial de la Comisión Centenario Colonización Judía en Colonia Mauricio: Carlos Casares, Argentina, 1991; Nro 6. Editora del Archivo; Carlos Casares: Buenos Aires, Argentina.

8. Dulout, L.N.; Flores, O. Costumbres tradicionales funerarias judías y su visualización dentro del Cementerio Israelita de La Plata. In En Patrimonio Cultural en Cementerios y Rituales de la Muerte; Tomo, I., Ed.; Comisión para la preservación del patrimonio histórico cultural de la Ciudad de Buenos Aires: Buenos Aires, Argentina, 2005; pp. 65-77.

9. Zablotsky, E. Filantropia no Asistencialista: Las Memorias de Boris Garfunkel Sobre Colonia Mauricio; Documento de Trabajo 479; Universidad del CEMA: Buenos Aires, Argentina, 2012; p. 56.

10. Haim, A. Argentina y la Historia de la Inmigracion Judia 1810-1950; Universitaria Magnes, Ed.; Universidad Hebrea de Jerusalén, AMIA Comunidad de Buenos Aires: Buenos Aires, Argentina, 1983.

11. Petric, M.P.; Knehtl, B.; Krause, A.; Militz, H.; Pavlic, M.; Pétrissans, M.; Rapp, A.; Tomazic, M.; Welzbacher, C.; Gérardin, P. Wettability of Waterborne Coatings on Chemically and Thermally Modified Pine Wood. J. Coat. Technol. Res. 2007, 4, 203-206. [CrossRef]

12. Xie, Y.; Krause, A.; Militz, H.; Steuernagel, L.; Mai, C. Effects of hydrophobation treatments of wood particles with an amino alkylsiloxane co-oligomer on properties of the ensuing polypropylene composites. Compos. Part A Appl. Sci. Manuf. 2013, 44, 32-39. [CrossRef]

13. Daud, N.; Shanks, R. Epoxy-silica composites replicating wood cell structure. Compos. Part A Appl. Sci. Manuf. 2014, 62, 11-15. [CrossRef] 
14. Giudice Carlos, A.; Alfieri, P.V.; Canosa, G. Decay resistance and dimensional stability of Araucaria angustifolia using siloxanes synthesized by sol-gel process. Int. Biodeterior. Biodegrad. 2013, 83, 166-170. [CrossRef]

15. Canosa, G.; Alfieri, P.V.; Giudice Carlos, A. Dimensional stability, fire performance and decay resistance in wood impregnated with alkylalkoxysilanes. Int. J. Eng. Innov. Technol. 2013, 3, 394-400.

16. Johannes, K.F. Silicones Reactive Polymers Fundamentals and Applications. In A Concise Guide to Industrial Polymers, 2nd ed.; A Volume in Plastics Design Library; 2013; Chapter 8; pp. 217-233.

17. Sonowal, J.; Gogoi, P.K. Dimensional Stability, Thermal Degradation and Termite Resistant Studies of Chemically Treated Wood. Int. J. Chem. 2010, 2, 218-225. [CrossRef]

18. Giudice, C.A.; Canosa, G.; Alfieri, P.V. Nanopinturas Híbridas de alto Contenido de Sólidos para la Protección de Fachadas; $7^{\circ}$ Expocongreso REPORT 2014 CABA; CABA: Buenos Aires, Argentina, 2014.

19. Canosa, G.; Alfieri, P.V.; Caprari, J.; Giudice, C. Performance of wood impregnated with alkoxysilanes. In Proceedings of the Congreso Euro-Americano REHABEND 2016 Sobre Patología de la Construcción, Tecnología de la Rehabilitación y Gestión del Patrimonio, Burgos, España, 24-27 May 2016.

20. Canosa, G.; Alfieri, P.V.; Giudice, C. Barnices antifúngicos hidrorrepelentes para la protección de maderas de baja densidad. In Proceedings of the 160 Congreso Internacional de Metalurgia y Materiales SAM-CONAMET 2016, Simposio Materiales y Tecnologías para la Industria Metalmecánica y Aeroespacial, Córdoba, Argentina, 22-25 November 2016; pp. 416-417.

21. Cui, G.; Liu, J.; Chen, C.; Li, C.; Shi, L. Study on silane impregnation for protection of high performance concrete. Procedia Eng. 2012, 27, 301-307.

22. Christodoulou, C.; Goodier, C.I.; Ausin, S.A.; Webb, J.; Glass, G.K. Long-term performance of surface impregnation of reinforced concrete structures with silane. Constr. Build. Mater. 2013, 48, 708-716. [CrossRef]

23. Ferrero, F.; Periolatto, M. Application of fluorinated compounds to cotton fabrics via sol-gel. Appl. Surf. Sci. 2013, 275, 201-207. [CrossRef]

24. Whelan, M.; Cassidy, J.; Duffy, B. Sol-gel sealing characteristics for corrosion resistance of anodised aluminium. Surf. Coat. Technol. 2013, 235, 86-96. [CrossRef]

25. Tortorelli, L. Maderas y Bosques Argentinos; EDITORIAL ACME: Buenos Aibes, Argentina, 1956; pp. 1-95. 910p.

26. Tortorelli, L. Glosario de Términos en Anatomía de Maderas; Revista de Inventario ForestalIV $\mathrm{N}^{\circ} 1$; Administración Nacional de Bosques de Buenos Aires: Buenos Aires, Argentina, 1963; pp. 3-32.

27. Roig, J.F. Bibliografía Sobre Estructura Demaderas Argentinas; Boletín de Extensión Científica N2; IADIZA: Mendoza, Argentina, 1996.

28. Jiménez, A.M.; Moglia, J.G. Árboles del Chaco Argentino: Guía para el Reconocimiento Dendrológico; $2003 ;$ p. 370. ISBN 987 95852-9-1.

29. Okan, T.; Köse, N.; Arifoglu, E.; Köse, C. Assessing ecotourism potential of traditional wooden architecture in rural areas: The case of Papart Valley. Sustainability 2016, 8, 974. [CrossRef]

30. Reinprecht, L.; Joscák, P. Reinforcement of model-damaged wooden elements, Part. 2. Restoration of wooden elements by the extension method using natural wood or epoxy-wood composite. Drevársky Vyskum-Wood Res. 1996, 41, 41-55.

31. Uzun, Z.; Köse, C.; Köse, N. A multidisciplinary study to reveal the historical value of wooden structures and to develop a conservation approach: Dere and Karlı Mosques in Samsun, Turkey. J. Cult. Heritage 2018. [CrossRef]

(C) 2018 by the authors. Licensee MDPI, Basel, Switzerland. This article is an open access article distributed under the terms and conditions of the Creative Commons Attribution (CC BY) license (http:/ / creativecommons.org/licenses/by/4.0/). 